\title{
Faktor Risiko Hiperbilirubinemia pada Bayi Lahir dari Ibu Diabetes Melitus
}

Dio R. Biade, ${ }^{*}$ Tunjung Wibowo, Setya Wandita, Ekawaty L. Haksari, Madarina Julia

Bagian Ilmu Kesehatan anak Fakultas Kedokteran Universitas Gadjah Mada (UGM)/ RSUP Dr. Sardjito, Yogyakarta

Latar belakang. Bayi yang lahir dari ibu diabetes mellitus (IDM) memiliki risiko lebih tinggi mengalami berbagai morbiditas pada masa neonatus. Metabolisme bilirubin merupakan salah satu sistem yang mungkin terganggu.

Tujuan. Mengetahui faktor risiko hiperbilirubinemia pada bayi IDM dan hubungannya dengan faktor risiko hiperbilirubinemia yang lain.

Metode. Studi kohort retrospektif pada 71 IDM dan 71 bayi ibu tidak diabetes melitus (ITDM) yang lahir di RSUP Dr.Sardjito antara Januari 2007 - Desember 2014. Data diperoleh dari register neonatal-perinatal WHO-SEARO.

Hasil. Risiko hiperbilirubinemia lebih tinggi pada bayi IDM dibandingkan ITDM (42\% vs 17\%) (RR=2,5 IK95\% 1,4-4,5). Analisis stratifikasi menunjukkan bahwa risiko dipengaruhi oleh usia kehamilan, berat lahir, polisitemia, dan inisiasi menyusu dini. Sepsis meningkatkan risiko pada IDM ( $R R=11,5$ IK95\% 3,7-36,0), sedangkan inisiasi menyusu dini merupakan faktor pencegah (RR=0,6, KI 95\% 0,3-0,9).

Kesimpulan. Ibu diabetes melitus meningkatkan risiko hiperbilirubinemia pada masa neonatus. Risiko ini dipengaruhi oleh berat lahir, usia kehamilan, kondisi sepsis, dan inisiasi menyusu dini. Sari Pediatrī 2016;18(1):6-11

Kata kunci: bayi baru lahir, ibu diabetes melitus, hiperbilirubinemia

\section{Risk Factors for Hyperbilirubinemia in Infants of Diabetic Mothers}

Dio R.Biade, Tunjung Wibowo, Setya Wandita, Ekawaty L. Haksari, Madarina Julia

Background. Infants of diabetic mothers (IDM) have higher risk for morbidities in neonatal period, including problems due to bilirubin metabolism.

Objective. To assess the risk for hyperbilirubinemia in IDM and its associations with other risk factors for hyperbilirubinemia. Methods. Retrospective cohort study on 71 IDM and 71 infants of non-diabetic mother (NIDM) who were born at Dr. Sardjito hospital between January 2007 and December 2014. Data were collected from the WHO-SEARO Neonatal - Perinatal Database. Results. Hyperbilirubinemia was more common in IDM than in NIDM (42\% vs 17\%), RR=2.5, 95\%CI 1.4 to 4.5. Further stratification showed that risk for hyperbilirubinemia was modified by birth weight, gestational age, sepsis, polycythemia and initial breastfeeding. Sepsis increased risk for hyperbilirubinemia, i.e. combined RR (95\%CI) of 11.5 (3.7-36.0). Initial breastfeeding protected IDM from hyperbilirubinemia ( $\mathrm{RR}=0.6,95 \% \mathrm{CI} 0.3$ to 0.9$)$.

Conclusion. Infants of diabetic mothers has increased risk for hyperbilirubinemia. The risk is modified by birth weight, gestational age, sepsis and initial breast feeding. Sari Pediatri 2016;18(1):6-11

Keyword: infant, diabetic mother, hyperbilirubinemia polysitemia

\footnotetext{
Alamat korespondensi: Dio Rakhmat Biade, Bagian Ilmu Kesehatan Anak, Fakultas Kedokteran Universitas Gadjah Mada/RSUP Dr. Sardjito Yogyakarta,
} Jalan Kesehatan No. 1 Sekip Yogyakarta 55284, Indonesia. Tel +62 (274) 561616,+62821 76356717, Fax +62 (274) 583745. E-mail: dio.biade@yahoo.com 
Dio R. Biade dkk: Faktor risiko hiperbilirubinemia pada bayi lahir dari ibu DM

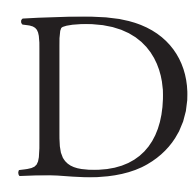
iabetes mellitus (DM) dalam kehamilan ialah gangguan toleransi glukosa yang terjadi dan atau baru diketahui pada saat kehamilan. Hal ini tanpa mempertimbangkan penggunaan insulin atau adanya gangguan toleransi glukosa yang mendahului kehamilan., ${ }^{1,2}$ Prevalensi prediabetes di Indonesia pada tahun 2007 sebesar 10\%, sedangkan diabetes melitus gestasional 1,9\%-3,6\%. ${ }^{3}$

Bayi dari ibu yang mengalami DM dalam kehamilannya akan mengalami peningkatan morbiditas pada saat konsepsi, fetal, neonatal, dan perkembangan selanjutnya. Risiko morbiditas pada bayi yang lahir dari ibu diabetes melitus dapat terjadi gangguan pada pertumbuhan, metabolisme glukosa, kalsium dan magnesium, status hematologi, fungsi jantung, fungsi respirasi, metabolisme bilirubin, dan fungsi neurologi. ${ }^{2,4,5}$

Pada bayi baru lahir, kejadian hiperbilirubinemia disebabkan oleh banyak hal, proses konjungasi yang tidak efektif karena sistem enzim glucuronosyltransferase belum sempurna menyebabkan terjadi peningkatan konsentrasi serum birirubin yang belum terkonjunggasi. ${ }^{2,4}$ Pada bayi yang lahir dari IDM, keadaan tersebut dapat semakin diperberat dengan kondisi polisitemia, makrosomia, dan sepsis.

Pada penelitian yang dilakukan oleh Opara $\mathrm{dkk}^{6}$ kejadian hiperbilirubinemia pada bayi IDM lebih tinggi bila dibandingkan pada bayi TIDM, yaitu 57,4\%. Pada penelitian lain dikatakan kejadian polisitemia secara signifikan akan meningkat pada bayi yang lahir dari IDM. ${ }^{7}$ Bayi dari ibu DM juga diduga memiliki sumber bilirubin lain yang berasal dari proses eritropoesis yang belum efektif. Kondisi tersebut diduga akan meningkatkan risiko hiperbilirubinemia pada bayi ibu DM. Penelitian ini bertujuan untuk mengetahui faktor risiko terjadinya kondisi hiperbilirubinemia pada bayi dari IDM.

\section{Metode}

Penelitian prospektif kohort yang merupakan kerjasama antara World Health Organization South-East Asia Region (WHO-SEARO) dan Divisi Neonatal FK UGM/ RSUP Dr. Sardjito dilakukan pada 1 Januari 2007 - 31 Desember 2014 di Instalasi Maternal Perinatal (IMP). Data mortalitas dan morbiditas neonatal dikumpulkan dengan menggunakan pre-coded kuesioner. Analisis dilakukan pada sebagian data bayi yang lahir dari ibu DM dengan kriteria inklusi bayi baru lahir dan dirawat di IMP RSUP Dr. Sardjito. Ibu penderita DM saat kehamilan pada kelompok terpapar atau ibu yang tidak menderita DM pada kelompok tidak terpapar. Subjek dieksklusi bila pulang dari rumah sakit atas keinginan sendiri atau data yang didapat tidak lengkap.

Besar sampel 71 bayi untuk setiap kelompok. ${ }^{9}$ Setiap bayi dari ibu DM yang diidentifikasi dipilih secara acak bayi dari ibu bukan DM yang dilahirkan pada minggu yang sama. Hiperbilirubinemia adalah kejadian peningkatan kadar bilirubin serum di atas kurva normal sesuai usia bayi pada saat pengukuran. Variabel lain yang dicatat adalah kejadian sepsis, hipoglikemia, berat lahir, usia kehamilan, dan inisiasi menyusu dini. Analisis data dilakukan dengan menggunakan program statistik SPSS-for-Window.

\section{Hasil}

Data yang lengkap menunjukkan 71 bayi lahir dari ibu DM dan 10.576 bayi lahir dari ibu tidak DM. Bayi yang lahir dari ibu tidak DM dilakukan random sample untuk mendapatkan jumlah data yang sama dengan bayi yang lahir dari ibu DM sebanyak 71 bayi. Dengan demikian, didapatkan 71 bayi lahir dari ibu DM dan 71 bayi yang lahir dari ibu tidak DM yang dilakukan analisis data.

Pada Tabel 2 tertera risiko hiperbilirubinemia pada bayi ibu DM RR 3,5 (RR 3,5 IK95\%: 1,7$7,4)$. Keadaan lain yang merupakan faktor risiko hiperbilirubinemia adalah kehamilan kurang bulan (RR 1,9 IK95\%:1,1-3,1), sepsis (RR 3,5 IK95\%: 2,1-5,7), hipoglikemia (RR 4,5 IK95\%: 2,6-7,8), polisitemia (RR 2,8 IK95\%: 1,4-5,5), dan inisiasi menyusui dini (RR 0,6 IK95\%: 0,2-1,5).

Pada Tabel 3 tertera peningkatan risiko hiperbilirubinemia pada bayi ibu DM, terutama terjadi pada bayi DM yang lahir cukup bulan (RR 4,8 IK95\%: 1,9-11,7) berat lahir cukup (RR 8,8 IK95\%: 2,2-35,9), polisitemia (RR 4,2 IK95\%: 1,2-14,9). Dapat dilihat juga bahwa faktor yang dapat mencegah hiperbilirubinemia pada bayi ibu DM adalah inisiasi menyusu dini (RR 0,6 IK95\%: 0,3-0,9).

\section{Pembahasan}

Hasil penelitian kami menunjukkan bahwa bayi dengan ibu diabetes melitus mempunyai risiko 
Tabel 1. Karakteristik dasar subyek penelitian

\begin{tabular}{lccc}
\hline Karakteristik & $\begin{array}{c}\text { Ibu DM } \\
\mathrm{n}=71(\%)\end{array}$ & $\begin{array}{c}\text { Ibu tidak DM } \\
\mathrm{n}=71(\%)\end{array}$ & $\mathrm{p}$ \\
\hline $\begin{array}{l}\text { Jenis kelamin } \\
\text { Laki-laki }\end{array}$ & $43(60)$ & $39(55)$ & 0,49 \\
$\quad$ Perempuan & $28(40)$ & $32(45)$ & \\
Usia kehamilan (bulan) & & & 0,68 \\
$\quad$ Kurang & $16(23)$ & $14(20)$ & \\
$\quad$ Cukup & $55(77)$ & $57(80)$ & $<0,001$ \\
Cara persalinan & $15(21)$ & $35(49)$ & \\
$\quad$ Normal & $56(79)$ & $36(51)$ & 0,49 ** \\
$\quad$ Tindakan & & $71(100)$ & \\
Antenatal care & $70(99)$ & $0(0)$ & 0,3 \\
$\quad$ Rutin & $1(1)$ & $2(3)$ & \\
$\quad$ Tidak rutin & & $69(97)$ & \\
Apgar menit 5 & $3(4)$ & & \\
$\quad<4$ & $68(96)$ & & \\
$>4$ & &
\end{tabular}

*diabetes melitus, ${ }^{* *}$ Fisher exact test

Tabel 2: Analisis bivariat faktor risiko hiperbilirubinemia

\begin{tabular}{|c|c|c|c|c|}
\hline \multirow[t]{2}{*}{ Variabel } & \multicolumn{2}{|c|}{ Hiperbilirubinemia } & \multirow[t]{2}{*}{ RR } & \multirow[t]{2}{*}{$\mathrm{p}$} \\
\hline & $\mathrm{Ya}$ & Tidak & & \\
\hline \multicolumn{5}{|l|}{ Ibu DM } \\
\hline Ya & $30(42)$ & $41(58)$ & $2,5(1,4-4,5)$ & 0,001 \\
\hline Tidak & $12(17)$ & $59(83)$ & & \\
\hline \multicolumn{5}{|c|}{ Usia kehamilan } \\
\hline Preterm & $14(47)$ & $16(53)$ & $1,9(1,1-3,1)$ & 0,02 \\
\hline Aterm & $28(25)$ & $84(75)$ & & \\
\hline \multicolumn{5}{|l|}{ Sepsis } \\
\hline Ya & $25(60)$ & $17(40)$ & $3,5(2,1-5,7)$ & $<0,001$ \\
\hline Tidak & $17(17)$ & $83(83)$ & & \\
\hline \multicolumn{5}{|l|}{ Hipoglikemia } \\
\hline Ya & $29(62)$ & $18(38)$ & $4,5(2,6-7,8)$ & $<0,001$ \\
\hline Tidak & $13(14)$ & $82(86)$ & & \\
\hline \multicolumn{5}{|c|}{ Berat lahir (gram) } \\
\hline$>4000$ & $6(32)$ & $13(68)$ & $1,1(0,5-2,2)$ & 0,04 \\
\hline $2500-3900$ & $18(22)$ & $64(78)$ & 1,0 (Referrence) & 0,01 \\
\hline$<2500$ & $18(44)$ & $23(56)$ & $2(1,2-3,4)$ & \\
\hline \multicolumn{5}{|l|}{ IMD } \\
\hline Ya & $4(17)$ & $18(83)$ & $0,6(0,2-1,5)$ & 0,31 \\
\hline Tidak & $38(32)$ & $82(68)$ & & \\
\hline \multicolumn{5}{|l|}{ Jenis kelamin } \\
\hline Laki-laki & $23(28)$ & $59(72)$ & $0,9(0,5-1,4)$ & 0,64 \\
\hline Perempuan & $19(32)$ & $41(68)$ & & \\
\hline \multicolumn{5}{|l|}{ Polisitemia } \\
\hline Ya & $2(100 \%)$ & $0(0 \%)$ & $2,8(1,4-5,5)$ & 0,04 \\
\hline Tidak & $40(29 \%)$ & $100(71 \%)$ & & \\
\hline
\end{tabular}

*Diabetes melitus 
Dio R. Biade dkk: Faktor risiko hiperbilirubinemia pada bayi lahir dari ibu DM

Tabel 3: Stratifikasi faktor risiko hiperbilirubinemia pada ibu diabetes melitus

\begin{tabular}{|c|c|c|c|c|c|}
\hline \multirow[t]{2}{*}{ Variabel } & \multirow[t]{2}{*}{ Ibu DM } & \multicolumn{2}{|c|}{ Hiperbilirubinemia } & \multirow{2}{*}{$\begin{array}{c}\text { RR } \\
\text { (IK95\%) }\end{array}$} & \multirow[t]{2}{*}{ MH } \\
\hline & & $\mathrm{Ya}$ & Tidak & & \\
\hline \multicolumn{6}{|c|}{ Berat lahir (gram) } \\
\hline \multirow[t]{2}{*}{$<2500$} & Ya & 6 & 11 & Undefined & \multirow{6}{*}{$\begin{array}{c}3,0(1,6-5,9) \\
\mathrm{p}=0,001\end{array}$} \\
\hline & Tidak & 0 & 2 & & \\
\hline \multirow[t]{2}{*}{$2500-4000$} & Ya & 16 & 23 & $8,8^{*}$ & \\
\hline & Tidak & 2 & 41 & $(2,2-35,9)$ & \\
\hline \multirow[t]{2}{*}{$>4000$} & Ya & 8 & 7 & 1,4 & \\
\hline & Tidak & 10 & 16 & $(0,7-2,7)$ & \\
\hline \multicolumn{6}{|c|}{ Usia kehamilan (minggu) } \\
\hline \multirow[t]{2}{*}{$<37$} & Ya & 7 & 9 & 0,9 & \multirow{4}{*}{$\begin{array}{c}2,4(1,4-4,3) ; \\
p=0,001\end{array}$} \\
\hline & Tidak & 7 & 7 & $(0,4-1,9)$ & \\
\hline \multirow{2}{*}{$37-40$} & Ya & 23 & 32 & $4,8^{*}$ & \\
\hline & Tidak & 5 & 52 & $(1,9-11,7)$ & \\
\hline \multicolumn{6}{|l|}{ Sepsis } \\
\hline \multirow[t]{2}{*}{$\mathrm{Ya}$} & Ya & 16 & 9 & 1,2 & \multirow{4}{*}{$\begin{array}{c}2,1(1,3-3,5) ; \\
\mathrm{p}=0,001\end{array}$} \\
\hline & Tidak & 9 & 8 & $(0,7-2,1)$ & \\
\hline \multirow[t]{2}{*}{ Tidak } & Ya & 14 & 32 & $5,5^{*}$ & \\
\hline & Tidak & 3 & 51 & $(1,8-17,9)$ & \\
\hline \multicolumn{6}{|l|}{ IMD } \\
\hline \multirow[t]{2}{*}{ Ya } & Ya & 4 & 5 & $0,57^{*}$ & \multirow{4}{*}{$\begin{array}{c}2,3(1,3-4,1) \\
\mathrm{p}=0,001\end{array}$} \\
\hline & Tidak & 0 & 13 & $(0,31-0,99)$ & \\
\hline \multirow[t]{2}{*}{ Tidak } & Ya & 26 & 36 & $2,0^{*}$ & \\
\hline & Tidak & 12 & 44 & $(1,1-3,6)$ & \\
\hline \multicolumn{6}{|l|}{ Polisitemia } \\
\hline \multirow[t]{2}{*}{ Ya } & Ya & 1 & 0 & 1,6 & \multirow{4}{*}{$\begin{array}{c}2,3 \\
(1,0-5,4)\end{array}$} \\
\hline & Tidak & 29 & 41 & $(0,5-5,1)$ & \\
\hline \multirow[t]{2}{*}{ Tidak } & $\mathrm{Ya}$ & 1 & 0 & 4,2 & \\
\hline & tidak & 11 & 59 & $(1,2-14,9)$ & \\
\hline
\end{tabular}

${ }^{*}$ Diabetes melitus

${ }^{* *}$ Exact Fisher test

lebih tinggi terjadi hiperbilirubinemia. Kejadian hiperbilirubinemia akan meningkat pada bayi IDM. Hal tersebut disebabkan proses konjugasi yang tidak efektif karena sistem enzim glucuronosyltransferase belum sempurna sehingga konsentrasi serum bilirubin yang belum terkonjugasi meningkat. Selain itu, bayi IDM memiliki sumber bilirubin lain yang berasal dari proses eritropoesis yang belum efektif. Prekursor sel darah merah yang beredar di pembuluh darah terjebak di lien dan dihancurkan. Pemecahan sel darah merah ini memberikan konstribusi terhadap beban bilirubin tambahan ke hati. Sistem proses bilirubin yang tidak efektif pada bayi baru lahir dari ibu DM menghasilkan kenaikan yang lebih cepat dari konsentrasi puncak serum bilirubin pada bayi. ${ }^{2}$
Analisis stratifikasi mendapatkan bahwa bayi IDM berat badan lahir $>4000 \mathrm{~g}$ merupakan faktor proteksi terjadinya hiperbilirubinemia, tetapi risiko meningkat pada bayi dengan berat lahir cukup. Hal tersebut menunjukkan bahwa berat lahir pada bayi dengan IDM merupakan faktor yang dapat memengaruhi kejadian hiperbilirubinemia. Namun demikian, hasil tersebut tidak sama dengan penelitian lain yang mengatakan bahwa kejadian hiperbilirubinemia pada makrosomia akan meningkat pada bayi yang lahir dari IDM. ${ }^{7}$

Hasil stratifikasi analisis lain menunjukkan bahwa bayi IDM yang lahir kurang bulan tidak memengaruhi hiperbilirubinemia. Sementara bayi yang lahir cukup bulan meningkatkan risiko hiperbilirubinemia. Usia 
kurang bulan maupun bayi ibu DM merupakan faktor risiko hiperbilirubinemia. Bayi kurang bulan, dari ibu DM atau bukan DM, mempunyai risiko lebih tinggi mengalami hiperbilirubinemia bila dibandingkan dengan bayi cukup bulan dari ibu bukan DM. Hal tersebut disebabkan karena semakin lama bayi berada di dalam kandungan maka hiperglikemia kronis akan berpengaruh pada janin yang diikuti hiperinsulinemia. Kondisi ini akan meningkatkan kebutuhan oksigen. Janin akan meningkatkan kosentrasi serum eritropoetin untuk memenuhi kebutuhan oksigen tersebut sehingga menyebabkan terjadinya polisitemia dan gangguan distribusi besi. ${ }^{2}$ Polisitemia merupakan faktor risiko hiperbilirubinemia, pada kondisi ini terjadi pemecahan sel darah merah yang berlebih, proses eritropoesis yang tidak efektif dan kemampuan hepar yang belum matang untuk mengonjungasi dan mengeksresi bilirubin. Jumlah sel darah merah yang berlebih menyebabkan peningkatan 30\% dari bilirubin yang harus dikonjungasi dan dieksresi oleh hati. ${ }^{2}$

Secara teori, sepsis merupakan faktor risiko untuk terjadinya hiperbilirubinemia. ${ }^{10}$ Sepsis maupun bayi ibu DM merupakan faktor risiko sepsis. Bila dibandingkan dengan bayi yang lahir dari ibu bukan DM dan tidak sepsis sebagai kelompok rujukan, bayi ibu DM yang mengalami sepsis mempunyai risiko paling tinggi untuk mengalami hiperbilirubinemia. Bayi yang mengalami sepsis bukan dari ibu DM atau bayi dari ibu DM yang tidak sepsis mempunyai risiko ditengahnya. Kemungkinan hiperbilirubinemia dapat terjadi pada semua bayi dengan atau tanpa risiko IDM, tetapi ketika bayi tidak sepsis kemungkinan terjadinya hiperbilirubinemia pada bayi dengan IDM akan meningkat. Pada kondisi sepsis terjadi infeksi sistemik yang dapat memengaruhi sistem metabolisme tubuh termasuk metabolisme bilirubin. ${ }^{10}$

Secara teori, polisitemia merupakan faktor risiko terjadinya hiperbilirubinemia. ${ }^{2}$ Polisitemia maupun bayi ibu DM merupakan faktor risiko sepsis. Bayi dengan ibu DM dan tidak DM yang mengalami polisitemia tidak mengalami perbedaan kejadian hiperbilirubinemia.Sebaliknya, bayi dengan ibu DM yang tidak memiliki polisitemia bila dibandingkan dengan bayi ibu tidak DM maka didapatkan peningkatan kejadian hiperbilirubinemia. Hal tersebut menunjukkan bahwa ibu DM dan polisitemia merupakan faktor risiko kejadian hiperbilirubinemia. Pada bayi dari ibu DM akan mengalami kejadian hiperinsulinemia pada saat kehamilan sehingga akan menyebabkan kondisi asfiksia pada janin saat usia kehamilan >30 minggu yang akan dikompensasi dengan pembentukan eritrosit yang lebih tinggi. Hal tersebut menyebabkan kondisi polisitemia pada bayi pada saat dilahirkan dan merupakan risiko kejadian hiperbilirubinemia pada saat pemecahan eritrosit.

Pemberian ASI awal merupakan faktor protektif yang dapat menurunkan risiko hiperbilirubinemia pada bayi IDM. Pemberian ASI sejak awal dapat membersihkan mekonium dengan segera sehingga dapat mencegah penyerapan kembali bilirubin yang tinggi pada mekonium. Selain itu, ASI dapat melapisi mukosa usus dan dapat mengikat bilirubin yang terkonjugasi untuk dikeluarkan bersama kotoran sehingga tidak terjadi penyerapan kembali bilirubin oleh usus. ${ }^{11}$

Hipoglikemia pada penelitian ini terlihat sebagai faktor independen yang dapat menyebabkan hiperbilirubinemia tanpa adanya kondisi ibu diabetes melitus pada bayi.

\section{Kesimpulan}

Ibu diabetes melitus merupakan faktor risiko untuk terjadinya hiperbilirubinemia pada bayi. Hal tersebut juga dapat tergantung pada kondisi berat badan pada saat lahir, usia kehamilan, sepsis, dan inisiasi menyusu dini.

\section{Daftar pustaka}

1. Mimouni FB, Mimouni G, Bental Y. Neonatal management of the infant of diabetic mother. Pediat therapeut 2013;4:1-4.

2. Nold JL, Michael K, Georgieff MD. Infant of diabetic mothers. Pediatr Clin N Am 2004;619-37.

3. Soewondo P, Pramono LA. Prevalence, characteristics, and predictors of pre-diabetes in Indonesia. Med J Indones 2011;20:283.

4. Edward S, Ogata MD. Problems of the infant of the diabetic mother. Neoreviews 2010;11:e627-31.

5. Fallucca F. Pathophysiology of diabetes in pregnancy. Ann. $1^{\text {st }}$. super sanita 1997;3:353-60

6. Opara P, Jaja T, Onubogu U. Morbidity and mortality amongst infans of diabetic mothers admitted into a special care baby unit in port harcouurt, Nigeria. Ital J of Ped 2010;36:1-77.

7. Cordero L, Rath K, Zheng K, Lando M, Nankervis C. Delivery room triage of large for gestational age infants 
of diabetic mothers. SAGE open medicine, 2004.

8. Madiyono B, Moeslichan S, Sastroasmoro S, Budiman I, Purwanto HS. Dalam: Sastroasmoro S, dan Ismael S, penyunting. Dasar-dasar metodologi penelitian klinis. Edisi keempat. Jakarta: CV Sagung Seto;2011.h.348-81.

9. Mahmood CB, Kayes MI. Problems and immediate outcome of infants of diabetic mothers. Bangladesh J Physc Surg 2008;26:68-72.

10. Gomella TL, Cunningham MD, Eyal FG. Neonatology management, procedures, on-call problems, disease, and drugs. Seventh edition. United State of America: Lange Mc Graw Hill Education;2013.

11. Rulina S, debby L. Buku bedah ASI IDAI. 2013. Diunduh pada 2 Februari 2016. Didapat dari: http:// idai.or.id/public-articles/kliniklasilair-susu-ibu-danikterus, html

12. Fallucca F. Pathophysiology of diabetes in pregnancy. Ann Ist Super Sanita 1997;3:353-60. 